Примљено: 27.9.2019. Ревидирана верзија: 18.11.2019. DOI: https://doi.org/10.46630/gsoc.23.2019.01

\title{
DAYTON AND RIGHT-WING NATIONALISM IN THE WEST
}

Abstract: The article looks at the question of why Western powers that claimed to be committed to multiculturalism fashioned a post-conflict agreement for BosniaHerzegovina that cemented in place the ethnicization of territory that had been the goal of ethno-nationalist elites. In particular, why did officials from societies where far right forces with ideological views very similar to the nationalist forces in Bosnia were seen as marginal, accept that view as the basis for the Dayton Agreement? The paper answers the question by looking at the way in which political space has been constructed in the liberal democracies of the West and the ways in which majorities in those states imagine that political space. The paper also draws a parallel between these centrist officials approving of the Dayton Agreement and the rise of right-wing nativist forces in their own societies.

Keywords: Bosnia-Herzegovina, Dayton Agreement, ethnic conflict, Yugoslav wars, post-conflict settlements, multiculturalism, nationalism

"[S]cholars and US military officers attending the two-day seminar appeared to be in almost unanimous agreement that current state boundaries in the Balkans should be redrawn to create 'smaller, more stable mono-ethnic states.' According to the delegates, new boundaries enshrining homogenous ethnic entities would follow the historical patterns and 'natural instincts' of Europe, as witnessed over the past 300 years." - Report on symposium on the future of US presence in the Balkans region, February 2001, Columbia University, NY (Domi, 2001).

Almost twenty-five years ago the Dayton Peace Agreement was signed by the presidents of Serbia, Croatia, and Bosnia-Herzegovina at an air force base in the US state of Ohio. ${ }^{2}$ The Agreement, which is still the law of the land in BosniaHerzegovina (hereafter referred to as Bosnia), included a constitution for the war-torn state drawn up by US diplomats (Annex 4), which, like every peace plan put forward by the West for the future of Bosnia (the Carrington-Cutileiro Plan; the Vance-Owen Plan; and the Owen-Stoltenberg Plan), divided the country into Serbian, Bosniak and Croatian territories, despite the fact that such a division did not reflect the pre-war

\footnotetext{
${ }^{1}$ vgagnon@ithaca.edu

${ }^{2}$ For the text see https://www.osce.org/bih/126173 (accessed 18 September 2019).
} 
demographics or the historical reality of the country. Such a division had, however, been a major goal for the purveyors of the war in Bosnia.

Indeed, what is striking about this agreement is that for the first time in Bosnia's history, particular territories were defined as "belonging" to particular national groups. Until the war, Bosnia's population had been very mixed - in 1991 only 18 out of 109 municipalities had a population that was 80 percent or more of one group, and the population of those municipalities made up less than 10 percent of Bosnia's total population. ${ }^{3}$ No specific municipality or other political unit had ever been assigned to specific national groups. Thus neither Serbs, Croats nor Bosniaks were officially considered to be "minorities" regardless of their numerical presence in any particular municipality or region. In this, Bosnia was unusual in a Europe of nation-states, where starting in the late $18^{\text {th }}$ century territory came to be identified with particular national groups (France for French, Germany for Germans, etc.), and with others in that territory becoming official minorities. ${ }^{4}$

Yet despite the purported goal of the West to maintain Bosnia's multicultural essence, the actual effect of the Dayton Agreement has been the opposite. The Serb entity that was established at Dayton, Republika Srpska (RS) - covering territory that before the war had a Serb population of less than 50 percent but that currently is 82 percent Serb - has consistently used the institutional power granted to it in the Dayton Constitution to stymie the functioning of a Bosnian state. Meanwhile, non-Serbs in RS, though formally having equal rights with all other citizens, ${ }^{5}$ know that they are in effect second-class citizens in a state ruled by ethnonationalist parties committed to separating RS from the rest of Bosnia. Likewise the Croat cantons in the other entity - the Federation of BosniaHerzegovina - are dominated by the Croatian Democratic Union (HDZ) and other likeminded Croat nationalist parties that are committed to creating a separate Croat entity; in those territories too non-Croats are effectively second-class citizens. ${ }^{6}$

So while the Dayton Agreement ended the war, it also created a situation where twenty-five years later Bosnia is still not a functioning state, and many of the people who run the various entities of the country are the same people responsible for the war. Both of these facts are due in very large part to the territorialization of ethnicity established by Dayton.

\footnotetext{
3 These included Serb-majority municipalities of Bosansko Grahovo, Titov Drvar, Šekovići, Bileća, Čelinac, Laktaši, Ljubinje and Srbac; Croat-majority Grude, Lištica, Ljubuški, Posušje, Čitluk, Duvno and Neum; and Muslim-majority Velika Kladuša, Cazin, and Živinice. The combined population of these municipalities amounted to 9.8 percent of the total population of Bosnia-Herzegovina. (Based on 1981 and 1991 census returns.)

4 On this historical process see Hobsbawm, 2012.

5 One large exception to this is that only Serbs can become a representative of RS in the Federal Bosnian Presidency. Although this provision of the Bosnian Constitution (Dayton Agreement Annex 4, Article 5) has been ruled a violation of human rights of RS's non-Serb citizens by the European Court of Human Rights in 2009, that ruling has had no practical effect on this provision. For a text of the ruling see Sejdic and Finci v. Bosnia and Herzegovina, 2009.

6 In addition, a Serb cannot according to the Constitution represent the Federation in the Presidency rather the positions are reserved only for Croats or Bosniaks.
} 
Given their proclaimed support for the preservation of a multicultural Bosnia, it is puzzling why Western diplomats and statesmen nevertheless acquiesced in the violent and forcible ethnicization of territory in Bosnia. On the one hand, there were "facts on the ground" at the end of the war, due to the massive ethnic cleansing undertaken by nationalist forces, and Dayton does include a right to return for people forcibly removed from their homes. On the other hand, the final Dayton Agreement maintained the territorialization of ethnicity that had been put forth in all the other Western peace plans (as mentioned above). The assumption from the beginning seemed to be, as noted in the epigraph to this paper, that "mono-ethnic states" were the most desirable outcome - a strange statement given that few if any western states are mono-ethnic.

Interestingly, over the past decade right-wing nationalist forces have come to the fore in a number of Western societies, forces that argue that a particular territory "belongs" exclusively to a specific ethnically and/or racially defined group and that the presence of others should be minimized - that is, that mono-ethnic states are desirable not just in the Balkans. These forces all have in common opposition to "multiculturalism" - they strongly disagree with the view that societies with ethnically and culturally diverse populations can be successful societies. Rather, they argue that such societies are doomed to failure. This is the same logic behind the territorialization of ethnicity in the Dayton and other peace agreements put forth for Bosnia, a logic noted in the epigraph to this article.

This right-wing nativist view, which until recently was seen as marginal in most Western societies, is often contrasted with the longer tradition in Western societies of acceptance and toleration. Of course all Western societies have historical records that are marked by exclusion and oppression of minorities. Yet the general view is that especially since the $1960 \mathrm{~s}$, Western societies have shifted so that the mainstream view is that of tolerance and acceptance of a multicultural presence. All of these societies have had extreme right-wing forces that reject that, and which are often dubbed as "racist", but up until recently they were seen as marginal in their respective societies, and for the most part had minimal political influence in the legislative process. In addition, the proposals for the ethnic division of Bosnia were not put forth by members of far right-wing nationalist parties or groups, but rather by diplomats and statesmen who were centrists within their own societies. ${ }^{7}$

The puzzle is why centrists who professed support for multiculturalism would put forward solutions to Bosnia that were ideologically in line with forces that in their own societies were seen as marginal and extremist. A seemingly unrelated puzzle is how and why such previously marginal forces have become major political forces in those societies, even vying for top positions and parliamentary majorities. In the case of the US, how could a society that is made up of descendants of immigrants, which has a long record of civil rights progress, come to be dominated by a nativist, extreme anti-immigrant administration that not so secretly pines after a white ethno-state?

\footnotetext{
7 There were also academics who argued for ethnic separation of populations as the only way for societal stability. See for example Kaufmann, 1996.
} 
This paper will argue that the shift in fact was not sudden; rather the way that political space has been constructed in the liberal democracies of the West predetermined the rise of forces who see their territory in ethnically and/or racially pure terms. Drawing on the work of Australian anthropologist Ghassan Hage, this paper argues that the Dayton Agreement that ended the Bosnian war is a prime piece of evidence that even liberals who see themselves as tolerant and accepting of multiculturalism in fact may have unstated assumptions about the demographic claims to the particular territorial state from which they come. I argue that the hegemonic way in which notions of belonging are conceptualized and implemented in the dominant liberal states of the West is itself a problem for plural societies. In the case of the successor states of the former Yugoslavia, this model has reinforced the logic of the ethnic cleansers, and has undermined the position of those forces in society that advocated for an authentic ethic of multiculturalism.

Indeed, as noted earlier, in the Balkans, we are faced with the puzzle of seemingly paradoxical behavior manifested by the West during and after the Yugoslav wars of the 1990s. On the one hand, observers in the West condemned the brutal violence against civilians, the murders and expulsions that have come to be known as "ethnic cleansing," decrying such acts as violations of liberal norms of human rights. On the other hand, however, the same observers have often seen violence as an almost natural outcome of the combination of ethnic diversity and a liberal democratic political system. In addition, as with the Dayton Agreement, they have based their actions and policies on that logic, often turning a blind eye to ethnic cleansing (the cases of Srebrenica in Bosnia and Operations Bljesak and Oluja in Croatia in the summer of 1995 come to mind), cooperating with ethnic cleansers in the name of pragmatism ${ }^{8}$, formulating policies and peace plans based on the territorialization of ethnicity as noted above, and finally, in the postwar era, ensuring the territorialization and institutionalization of ethnicity, a focus on ensuring "minority" rights within the framework of nationally-defined states or entities, and attempting to teach the locals liberal values such as tolerance, all in the name of bringing stability and liberalism to the region. However, these policies have served to reinforce the logic of the ethnic cleansers and to silence and demobilize other, possible alternative ways of thinking about political space. As noted above, they have also ensured that BosniaHerzegovina remains a non-functioning state dominated by nationalist forces.

One reason for these outcomes is the liberal model's understanding of the causes of the violence described as "ethnic conflict," in particular its assumption that the existence of substantial "minority" populations, or the lack of a culturally defined homogeneity, is a major problem for societies. From this perspective, cultural pluralism is a problem to be managed or overcome in order to prevent the outbreak

\footnotetext{
${ }^{8}$ For example, both Serbian President Slobodan Milošević and Croatian President Franjo Tuđman were treated as valued negotiating partners despite the knowledge that both were also responsible for massive human rights abuses. A particularly interesting example of this at the time could be seen in the New York Times report on the Dayton negotiations, in which U.S. negotiators portray Milošević as a reasonable and effective negotiating partner, while Bosnian President Alija Izetbegović was portrayed as cranky and difficult. See Sciolino and Cohen, 1995.
} 
of violence along ethnic lines (Kaufmann, 1996). It is this often unstated, underlying assumption that drives the policy of "liberal multiculturalism."

Yet, as I have shown elsewhere, in the case of the former Yugoslavia, sustained violence was not caused by the fact that many regions of the country were ethnically plural. Rather, the ultimate cause of the violence was to be found in the interests and values of parts of the ruling elites in Serbia and Croatia, in the challenges and threats they were facing from the wider populations in their republics who were mobilizing for basic changes in the structures of political and economic power, whose main concerns were nonethnic ones. The violence and the imposition of ethnic homogeneity was a purposeful and strategic policy undertaken by certain elites in response to those threats. In an attempt to impose political homogeneity at home, they used violence framed in ethnic terms in order to demobilize, silence, and marginalize these challengers. In other words, the violence was not the result of cultural pluralism, but rather was a means by which to construct a society segmented by ethnic identity; violence thus creates a society that fits the liberal preconceptions of plural societies (Gagnon, 2004; Gagnon, 2020).

Given their claims to be tolerant, multicultural societies themselves, why did the West accept the discourse of ethnicity almost unquestioningly, and pursue policies in the region that reinforce ethnicization and thus the consolidation in power of right-wing nationalist forces?

In answering these questions, I argue that those local actors who pursued an ethnicized strategy of violence were acting not out of some innate Balkan pathology, but rather according to an ethnicist logic that reflects western nation-state building, or, in the words of the Report of the Columbia University symposium cited at the start of this article, "the historical patterns and 'natural instincts' of Europe" (Domi, 2001). Ironically, the threat to the security of states that are not ethnically homogeneous comes not from their heterogeneity, or from the existence of "minorities," but rather from the unproblematic acceptance of this particular conceptualization of national space, which by its very nature constructs parts of the population as "minorities." Those who call for ethnically pure states as a means to ensure stability have seriously misidentified the causes of instability. Indeed, the concept - and policy - of ethnic purity, and of ethnically-defined liberal states, itself is a cause of instability. The implicit assumption is that ethnically diverse communities or states are not possible without either massive repression or the territorialization of "ethnic groups." The latter method, apparently preferred by the West, involves the construction of an ethnicized "hierarchy" that assigns states to specific "ethnic groups" and treats others within that territory as "minorities" to be tolerated.

\section{The Yugoslav wars of the 1990s: What they were not}

The starting point for this analysis is the sharp contrast between Western portrayals of the violence in Croatia and Bosnia and the actual situation on the ground in both places. In particular, despite Western conceptions, the violence in both places was not caused by preexisting hatreds, but rather was purposefully and 
strategically imposed on the most ethnically diverse communities from outside, as a result of policies in Belgrade and Zagreb.

The puzzle here is thus not why Serbia's elites pursued a strategy of violence - indeed, strategies of violence are quite common - but rather why they pursued such a policy in the name of an ethnic nationalist imagining of space that was so contrary to the realities on the ground, that did not reflect grassroots sentiments in the affected communities, and that resulted in the destruction of those communities, and in particular, the expulsion, murder, or displacement of the vast majority of Serbs in Croatia, Bosnia, and Kosovo ${ }^{9 *}$. A similar puzzle is presented by the actions of Croatia's leadership, which had the same effects on Croats in the ethnically mixed parts of Croatia and Bosnia.

Indeed, even a cursory glance at the data gathered by Yugoslav social scientists on interethnic relations in pre-1990 Yugoslavia is enough to show that ethnic relations were not the cause of the violent conflicts that wracked the region in the $1990 \mathrm{~s} .{ }^{10}$ In all republics, but especially in Bosnia-Herzegovina, the site of the bloodiest and longest war, what is clear from pre-war polling is that people prioritized questions of economic reform and their standard of living, not an ethno-nationalist agenda. Symptomatic of this were the extremely high ratings received by federal prime minister Ante Marković in his two years of leading the federal government in the direction of reform, as well as other polls showing priority given to issues of the economy over narrowly ethnic issues (Baćević, 1991). ${ }^{11}$

In addition to this data on the state of Yugoslav society in the years prior to the war, one can also look at the actions and motivations of those political elites who were responsible for the widespread violence. Suffice it to say here that impending radical changes in the structure of economic and political power affected different parts of each republic's elites in differing ways. Some - "reformists" or "liberals" welcomed and indeed pushed for such change, while others - "conservatives" - were extremely opposed to them (Gagnon, 2004). Beginning in 1987, with the victory of the faction in Serbia led by Slobodan Milošević, this conflict between reformists and conservatives gradually came to consume first the League of Communists of Yugoslavia, and eventually the Socialist Federal Republic of Yugoslavia. The violence itself was a strategic policy on the part of conservative elites, especially in Belgrade and in Zagreb (where, from 1989 onward these elites were the leaders of the ruling HDZ), who sought to reconstruct the meaning of ethnicity, that is, what it meant to be "Serb" or "Croat," with the goal of ensuring nationally-defined authoritarian states. This strategy was not a means to mobilize populations, however. Rather, the violence served mainly to demobilize, silence and marginalize those challenger elites as well

\footnotetext{
${ }^{9}$ This designation is without prejudice to positions on status, and is in line with UNSCR 1244/1999 and the ICJ Opinion on the Kosovo declaration of independence. (Editorial note)

${ }^{10}$ See for example, Dugandžija, 1991; Oliveira-Roca, 1991; Pupovac, 1991; Bakić, 1989; Bakić and Dunđerović, 1990; Hodson, Massey and Sekulic, 1993.

${ }^{11}$ For information from Croatia in the 1990s, see "Anketa istraživanja IZBORI 1990, 1992, 1995," in Kasapović, 2001.
} 
as the large parts of the population who had been mobilizing for reforms in the late 1980s and in 1990 (Gagnon, 2004; Gagnon, 2010).

The question remains, however, as to why this violence was undertaken within a discourse of ethnicity, why the violence was framed as ethnic violence, why it was portrayed as the result of ethnic solidarity. Here it is necessary to look at how the international norms of state-building have developed since the 19th century, as well as how the West reacted to the violence and to the discourse of ethnicity that marked the Yugoslav wars of the 1990s.

\section{Conceptions of Political Space in Europe: The Europeanization of the Balkans}

Thinking of political space in ethno-nationalist terms is a European tradition. In brief, pre-nationalist conceptualizations of space were based on dynastic empires with very culturally heterogeneous populations. Such heterogeneity was not problematic because there was no direct link between language, "ethnicity," and politics. What tied the populations of these empires together was their status as subjects of the reigning dynasty; their language or "ethnicity" were basically irrelevant (though at times certain linguistic or religious traits gave advantages to parts of the population). The new, nationalist way of imagining political space - motivated by modernization processes as well as by the growing participation of larger parts of the population in various functions of the state - meant that now the characteristics of the population within the borders of the state were crucial to this imagining. The result was a series of conscious and strategic acts on the part of elites to construct an image of a population with a common "national" culture and identity, to impose that culture on the actual population, and to try to erase previous forms and images of coexistence and pluralism in constructing the narrative of the nation.

The literature on nationalism makes quite clear that this shift was not "natural," that is, ethno-national states arose not as a reflection of some pre-existing reality on the ground that merely "awoke" after a long period of slumber or repression. While drawing on what Hobsbawm refers to as "proto-national" factors, the phenomenon of space conceived of in ethnically or linguistically homogeneous terms was very much a new one that was constructed purposefully by state-building elites, in which proto-national elements were reshaped and reified, and given new, political meanings as a way of trying to create political homogeneity (Hobsbawm, 2012; Gellner, 2009). Indeed, given that the territorial spaces in question were neither culturally nor politically homogeneous, one of the major parts of the nation-state project in Western Europe was the construction of this homogeneity. As Hobsbawm points out, early to mid-19th century liberals saw this move towards cultural homogeneity - and the disappearance of smaller "peoples" - as a step toward progress. The means by which various state elites fostered or imposed homogeneity differed, ranging from the use of violence against populations which did not fit into the newly ethnic designation of political space - non-French speakers in France, aboriginal peoples in colonized 
countries, Jews and Gypsies in Europe - to imposing homogeneity through education and linguistic standardization (assimilation and differentiation of regional variants of language and culture by social status). This entire range of strategies has marked the construction and reconstruction of Western European nation states - as well as the European settler states in North America, southern Africa, and Australasia - right up to the end of the 20th century.

This move toward an "ethnic" homogenization of political space is thus clearly a Western European phenomenon that, while not the result of instinct (as claimed by the participants in the Columbia University conference cited at the beginning of this paper), has certainly been and continues to be the hegemonic way that political space has been imagined and constructed in Western Europe, as well as in the European settler states. It also spread with European colonialism and (more recently) with liberal democracy to other areas of the world, where it has been superimposed over local, complex and plural conceptions and understandings of identities and their links to political space. The result has often been the similar logic of "ethnic cleansing" and violence to make demographic realities on the ground conform to these ideas of homogeneous political space. Indeed, as Michael Mann points out, "genocide can be seen ... as 'the dark side of democracy'- the most undesirable consequence of the modern practice of vesting political legitimacy in "the people"" (Mann, 1999).

This reconceptualization of political space in Western Europe over the course of the 19th century also had its impact in the Balkans, where, as it had throughout Europe, this idea clashed sharply with the demographic and social realities on the ground. The import of this West European idea into Southeastern Europe would thus lead one to expect a repeat of the various types of "ethnic cleansing" that had been carried out throughout the continent. Such violence was thus the result not of "ancient hatreds," but rather of the spread of the logic of liberal West European imaginings of political space.

Indeed, the very different, very heterogeneous realities in the Ottoman and Habsburg empires came under increasing pressure as the ideas of homogeneous ethnic nations spread from the West. Elites who wished to lay claim to a state on the territory of either empire had to frame the claim in European terms of an ethnic/linguistic nation, despite the fact that no territory in the region conformed to that demand. In the case of the Ottoman Empire, the Western powers also directly intervened by claiming certain religiously-defined populations to be under their "protection," effectively putting certain parts of the Ottoman population under their patronage and recognizing as the local populations' leaders those elites who mobilized a discourse of ethno-religious separatism and boundedness. Thus, the West European model of the nation-state

was imposed on all the Ottoman peoples by their leaders regardless of their historical experience and political culture. Each major ethnic group ... sharing a kindred language was assembled arbitrarily in a given territory and forced to accept a national identity chosen by the self-appointed 'national' leaders (Karpat, 1982, p.166). 
The result was the violence and wars in the Balkans over the course of the 19th and early 20th centuries, including the effective "ethnic cleansing" of Ottoman Muslims from the territories of newly independent nation-states (McCarthy, 1995). Far from being the result of endemic hatreds or Balkan pathologies, however, they were the result of a reconceptualization of space along European lines, in effect the "Europeanization of the Balkans."

The elites who were successful in establishing a Serbian state thus used a discourse and an image of a "Serbian people" to construct the territorialized sense of nation. The state-building nationalism that drove these policies was first officially enunciated in 1844 by the minister of internal affairs of the Serbian principality, Ilija Garašanin, who argued that "Serbia must place herself in the ranks of other European states." Garašanin, who today is often portrayed outside of Serbia in negative terms as the father of Serbian nationalism, laid out a basically liberal vision of a large Serbian-dominated state in what was then the European realms of the Ottoman Empire, as well as in the South Slavic realms of the Habsburg Empire. A major contributor to Garašanin's Načertanije, in which he laid out this vision, was Czech lawyer and soldier František Zach. Zach, from the Habsburg Empire, was a liberal and a Slavic nationalist whose views reflected the liberal views on state-building of the time. ${ }^{12}$

In this move to assert an independent Serbia policy, the ruling elites of the principality were thus following in the footsteps of other European liberals, and were also very strongly supported by Western powers who sought to prevent Russian influence and control over the region. The strategy of the Western powers was to establish West European-style nation states in the region regardless of the demographic realities on the ground. As a result, just like European states earlier, Serbian elites also undertook to impose a cultural homogeneity on their new nationstate's territory, in this case expelling the Muslim populations from the territories that became incorporated into Serbia. As Hobsbawm points out, this homogenization was part and parcel of mid-19th century liberalism and its vision of progress (Hobsbawm, 2010, pp.30-33).

As Serbian territory expanded, the Europeanization of these territories continued, as Serbian elites sought to ensure the ethnicization (or more specifically, the Serbification) of that territory. The Balkan wars of 1912-1913 likewise saw fighting over territories that had been Ottoman, with very diverse populations. Yet neighboring nation-states also laid claim to these Ottoman territories based on ethnic, linguistic, religious grounds. Given the dissonance between the social-demographic realities and the requirement of ethnic claims to territory, the wars themselves must be seen as attempts by these states to force an ethnic conceptualization of space onto this diverse space. The result - ethnic cleansing in the form of massacres and expulsions - was part of this attempt to get the Western powers to accept claims to the territory. Western acceptance of course did not mean the West actively condoned expulsions;

${ }^{12}$ For an analysis of Garašanin’s “Načertanije," see Bataković, 1994. On Zach’s role, see Bataković, 2014, pp.135-161. 
indeed, ironically, the violence was portrayed in terms of ancient Balkan enmities and primitive passions, and the West stepped in to ensure "minority rights" for those who did not fit the new description of the conquered space (Carnegie Endowment, 1993). But the very notion of people who had lived in territories their whole lives, as had their ancestors, suddenly becoming "minorities," along liberal Wilsonian lines, showed that in effect the Western liberals, just as much as the extremist nationalists, shared a basic conceptualization of political space in ethnic terms.

Yet there were alternative discourses; in Serbia, when the region that would eventually become the Yugoslav Republic of Macedonia was conquered, the opposition Socialist Party argued strenuously that the population there should not be reduced to second-class "minority" status; rather, they pushed for Macedonians to have full civil and political rights. ${ }^{13}$ Indeed, in terms of on-the-ground lived experiences, the most ethnically diverse parts of what became the state of Yugoslavia maintained those realities up until the wars in 1991 and 1992, and some survived even afterwards. ${ }^{14}$ These two conceptualizations of space continued to battle: on the one hand the imagining of ethnically defined nation-states, with some arguing for ethnic exclusivity and even expulsions to create homogeneous space, and others arguing for tolerance and liberal minority rights; and on the other hand the realities on the ground of plural, multiethnic communities. It seems contradictory that the West has effectively come down on the side of those who have used violence to achieve the ethnicization of territory and the territorialization of ethnicity - which after all is a long tradition among liberal states in the West - while at the same time demanding that the Balkan natives accept an ethos of multiculturalism. But as will be explained below, these two apparently contradictory policies are in fact merely two sides of the same coin, and are based on the same logic that Western states themselves have conceptualized political space.

It thus also seems highly ironic that Western analyses of the wars in Yugoslavia often treat them as something essentially different, as Balkan pathologies that are fundamentally alien to anything in the West. This irony is made all the greater given the West's attempts to teach the Balkan natives to be good, liberal, tolerant multiculturalists, when in fact the West's attempts to impose liberal multiculturalism have actually served to reinforce those factors in ex-Yugoslav societies that are the most nationalistic and ethnicist. ${ }^{15}$

\footnotetext{
${ }^{13}$ See the discussion of the Serbian opposition's strong criticisms of the ruling party's views on how to govern the newly conquered territories in what is now the Republic of Macedonia in Carnegie Endowment, 1993; for the same issue applied to Kosovo*, see Stefanović, 2005.

${ }^{14}$ See for example Dimitrijević, 2000.

${ }^{15}$ In the words of Maria Todorova, "It is, of course, a sublime irony to observe leaders of the cleansed societies of Western Europe fifty years after their ugliest performance raise their hands in horror and bombard ... the former Yugoslavs in preserving 'ethnic diversity' for the sake of securing a Volksmuseum of multiculturalism in the corner of Europe, after having given the green light to precisely the opposite process." (Todorova, 1997, p.186). What Todorova misses is that the policy of "multiculturalism," both in the west and in the Balkans, is merely a continuation of the logic of ethnic cleansing, but in a friendly, liberal form rather than in a nasty, bloody form.
} 
Thus as noted earlier, from the start of the war in Bosnia, every peace plan put forth by the West proposed to divide the republic into ethnically defined territorial units - districts, cantons, entities: all were based on the territorialization of ethnicity and the ethnification of territory. The November 1995 Dayton Peace Agreement that actually ended the war went one step further. It not only divided the country into ethnically-defined entities, it then divided one of those entities into ethnicallydefined cantons. The Dayton Constitution, which was written by American officials, also allocated positions in the Bosnian parliament and the presidency by ethnicity, reinforcing and reifying the very logic that Dayton claims to oppose, that is, the logic of the ethnic cleansers. ${ }^{16}$ Of course Dayton also contained provisions to ensure "minority populations" all civil and political rights, and to allow "minorities" to return to their prewar homes. But as Tone Bringa has pointed out, in pre-war Bosnia Serbs, Muslims and Croats were not minorities anywhere in the Republic (Bringa, 1995). Now they are.

To be sure, the local nationalist parties in Bosnia itself (as well as the ruling parties in Croatia and Serbia) favored this approach, going so far as to sacrifice members of "their" nation in order to achieve those goals. ${ }^{17}$ What is of interest however is the fact that Western ways of thinking about territory coincided with the local nationalists' own goals. That is, the form of violence seen in the Yugoslav wars of the 1990s, the discourse within which it was carried out, and the effects it had on the ground, were very much in line with dominant Western conceptualizations of political space. While the West has condemned the violence, it has accepted and indeed even promoted the logic of the violence - ethnification of territory, and territorialization of ethnicity - because it is a logic on which the nation-states of Western Europe and even the so called "civic nationalisms" of the US, Canada, and Australia were themselves formed and on which they are still based in the eyes of many citizens of those countries (although in the latter cases the "ethnic" definition of the state is based on the concept of "whiteness"). ${ }^{18}$

Indeed, the very call for tolerance and minority rights is based on the same logic that underlies the actions of the ethnic cleansers, that is, that each "ethnic group" has the right to its own territorial national state. Of course the liberal model does not call for ethnic cleansing; its focus is on tolerance and the granting of rights to "minorities." But as Australian anthropologist Ghassan Hage has pointed out in

\footnotetext{
${ }^{16}$ While in socialist Bosnia there was an "ethnic key" that provided for representation of the various groups in Bosnia in state and other official positions, including the presidency, this was a far cry from what was put into place by Dayton. For example, in the elections for members of the Bosnian Presidency within Socialist Yugoslavia, all Bosnian's voted for who would be the Serb member; likewise for the Croat and Muslim members.

${ }^{17}$ See for example Božić, 2018.

${ }^{18}$ To be sure, alternative non-ethnic versions of identity compete with these ethnic ones; but the dominant, hegemonic vision of national identity is, in all these cases, an ethnically defined "whiteness". Those who advocate an inclusive vision of national belonging are fighting an uphill battle in all of these societies. For an example from the United States, see Gerstle, 2002; Horsman, 1986. For an example from France, see Maschino, 2002, 6-7.
} 
his work on multiculturalism, the main difference between the "bad" nationalists who want to exclude minorities, and the "good" liberal nationalists who call for toleration, is a matter of degree (Hage, 2000). In both cases the choice of tolerating or not tolerating is assumed to belong to those who feel entitled to determine the fate of a particular national territory; the ethnification of territory as a principle is not in question. In both cases, national space is imagined as "belonging" to people of the dominant culture, defined ethnically, who feel themselves empowered to be the arbiters of the fate of that space. Thus in a liberal nationalist Croatia, people who identify as Croats felt themselves empowered to have authority to tolerate or to not tolerate Serbs, to grant them "equal rights" or to see them as a security threat to the Croatian state. The Serb "minority," on the other hand, does not tolerate others; in Hage's terms, "those in a dominated position do not tolerate, they just endure" (Hage, 2000, p.88). ${ }^{19}$

\section{Liberal Multiculturalism in the West as an ethnicist project}

Why have Western policy makers so easily adopted the logic of the ethnic cleansers? It is because, as Australian anthropologist Ghassan Hage has convincingly argued, the West's own conception and policies of liberal multiculturalism are themselves forms of ethnic nationalism, policies that serve in their own states and societies to reinforce the fantasy of White supremacy (Hage, 2000). Although not as obviously offensive as overtly racist, "evil" nationalists, this liberal multiculturalism in Australia, North America, and Western Europe, serves to position whites as the arbiters of national essence. Thus it is whites who are called on to be tolerant, which implicitly recognizes that they are also the ones who feel entitled to be intolerant. Their decision not to exercise their ability to be intolerant is seen as an act of benevolence and generosity. Whites are told they should value diversity, that is, that it is good to "have" minorities because they provide something important to the whites (as opposed to merely recognizing that "we are diverse"). In short, whites implicitly and naturally assume that it is up to them to accept or reject non-whites as parts of their societies, to grant or withhold rights and a place in society. Whites in effect assume themselves to have the privileged position as the managers of national space. As such, liberal multiculturalism is a nationalism of inclusion; that is, its threshold of tolerance is higher than the nationalism of exclusion, but it is still nevertheless present.

As Cornel West expresses it in the US context,

“[F]or liberals, black people are to be 'included' and 'integrated' in 'our' society and culture... [but they] fail to see that the presence and predicaments of black people are neither additions to nor defections from American life, but rather constitute elements of that life" (West, 1994, p.6).

\footnotetext{
${ }^{19}$ Or in the words of the Ashanti Prince Kwame Poku, in Arthur Japin's novel of displacement and identity, "Being tolerated signifies not being equal" (Japin, 2002, p.274).
} 
As another African-American scholar has described it, African-Americans are considered to be "like one of the family," though not exactly one of the family (Collins, 2001). So despite the claims that the U.S. is based not on the "bad" ethnic nationalism, but rather "good" civic nationalism, what becomes clear in this analysis and in other African-American critiques of American identity is that the US too bases belonging and membership on ethnic criteria (Collins, 2001, p.10). ${ }^{20}$ In this case, however, the ethnic category is an overarching "White" identity, where non-whites are systematically treated as second-class citizens, and in which European and other immigrants do their best to "become white," or to assimilate to the dominant culture, because it is members of the dominant culture who are the managers of national space. ${ }^{21}$ Thus it is "White" Americans who are asked to be tolerant and generous, to appreciate the diversity that "minority" populations bring to their country. It is also "White" Americans who pronounce on the desirability or dangers of a lack of assimilation of newcomers, on the need for assimilation of native minorities into the mainstream culture, on the levels of immigration and diversity that are acceptable or excessive.

Given this background, it is no surprise that right-wing forces that openly advocate for ethnically pure states in the West have come to positions of prominence throughout the West. Indeed, many of them look to the actions of Serbian nationalists as inspiration - the shooter in the New Zealand mosque shooting even specifically citing Radovan Karadžić as an inspiration (Živanović, 2019; Hajdarpašić, 2019).

In this sense, the Dayton Agreement, though crafted by centrist liberal politicians in the West, is based on the same logic as the right-wing nationalist forces that have seemed to be ascendant in the U.S. and Europe. Though not a coincidence, it shows how the thinking behind Dayton was a sign that, as Hage notes, many in Western societies do think of the "space" of their state as belonging to the dominant group. They are however much more tolerant of others than the White ethno-nationalists.

Transported to the Balkans, while the West condemned "bad" nationalists who overtly called for and carried out ethnic cleansing, what it promoted in fact follows a similar logic, though with a different threshold of tolerance for "minority" populations. While of course, as Hage points out, for "minorities" it is preferable to live in a state dominated by "good" nationalists rather than "bad," the problem is that because they are looking at national space based on the same assumptions, the proportions of "good" and "bad" can rapidly shift. And indeed that is what we have been seeing in Western societies over the past several years. Thus the fact that U.S. and EU diplomats accepted the ethnicization of territory in Bosnia was an indication that this mode of thinking was not foreign to them, but rather was consistent with how they viewed political space. The quote at the beginning of this article, though at the time spoken about the Balkans and Europe, could just as easily have been stated by White nationalists who seek to ensure that the US and European states become white

\footnotetext{
${ }^{20}$ For an analysis of US identity as being centered on "whiteness," see Marable, 1993.

${ }^{21}$ On how immigrants to the United States become white, see Roediger, 2005 and Ignatiev, 1995. Hage also has an interesting analysis of the hierarchy within Australian whiteness (Hage, 2000).
} 
ethno-states. In that sense, we can see the war in Bosnia and the Dayton Agreement as a precursor to current political trends in the West.

\section{References}

Baćević, Liljana. (1991). Jugoslavija na kriznoj prekretnici. Belgrade: Centar za politikološka istraživanja i javno mnenje, Institut društvenih nauka, Univerzitet u Beogradu.

Bahtijerević, Štefica, Lazić, Mladen, Goati, Vladimir, Milas, Goran, Miljević, Milan, Mihajlovski, Stojmen ... Vasović, Mirjana. (1991). Položaj naroda i međunacionalni odnosi u Hrvatskoj. Zagreb, Institute for Social Research.

Bakić, Ibrahim. (1989). "Stavovi mladih Bosne i Hercegovine prema naciji i religiji." Sveske, no.24-25.

Bakić, Ibrahim, \& Dunđerović, Ratko. (1990, 22 March). “Građani Bosne i Hercegovine o međunacionalnim odnosima.” Oslobođenje.

Bataković, Dušan T. (1994). “Ilija Garašanin’s 'Načertanije': A Reassessment.” Balkanica, $35(1), 157-183$.

Bataković, Dušan T. (2014). The Foreign Policy of Serbia (1844-1867): Ilija Garašanin's Načertanije. Belgrade: Institute for Balkan Studies, Serbian Academy of Sciences and Arts.

Božić, Gordana. (2018). Variations in Political Violence: Civil War in Bosnia and Hergezovina, 1992-1993. Unpublished $\mathrm{PhD}$ dissertation, University of Ottawa, Ottawa, Ontario, Canada.

Bringa, Tone. (1995). Being Muslim the Bosnian Way. Princeton: Princeton University Press.

Carnegie Endowment. (1993). The Other Balkans: A 1913 Carnegie Endowment Inquiry in Retrospect. Washington, DC: Carnegie Endowment.

Collins, Patricia Hill. (2001). "Like one of the family: race, ethnicity, and the paradox of US national identity." Ethnic and Racial Studies, 24(1), 3-28.

Dimitrijević, Nenad. (2000). "Managing Distrust and Hatred: Multiethnic Local Communities in the Countries of the Former Yugoslavia / Upravljanje Nepovjerenjem i mržnjom: multietničke lokalne zajednice u zemljama bivše Jugoslavije.” In Nenad Dimitrijević (Ed.), Managing Multiethnic Local Communities in the Countries of the Former Yugoslavia - Upravljanje multietničkim lokalnim zajednicama u zemljama bivše Jugoslavije (pp.3-28). Budapest: Open Society Institute.

Domi, Tanja. (2001, March 2). "US to Rethink Bosnia Policy?” International War and Peace Report's Balkan Crisis Report, No. 223 (part one).

Dugandžija, Nikola. (1991). "Domet Nacionalne Zaokupljenosti." Pp.135-152 in Bahtijarević et al 1991 (in English as: "The Level of National Absorption," in Katarina Prpić, Blaženka Despot, and Nikola Dugandžija (Eds.), Croatian Society on the Eve of Transition. Zagreb: Institute for Social Research, 1993.

Gagnon, Chip. (2010). "Yugoslavia in 1989 and after." Nationalities Papers. 38(1), 23-39. 
Gagnon, V.P., Jr. (2004). The Myth of Ethnic War: Serbia and Croatia in the 1990s. Ithaca, NY: Cornell University Press.

Gagnon, V.P., Jr. (2020). Mit o etničkom ratu: Srbija i Hrvatska devedesetih godina. Beograd: Barabas (forthcoming).

Gellner, Ernst. (2009). Nations and Nationalism. Ithaca: Cornell University Press.

Gerstle, Gary. (2002). American Crucible: Race and Nation in the Twentieth Century. Princeton: Princeton University Press.

Hage, Ghassan. (2000). White Nation: Fantasies of White supremacy in a multicultural society. New York: Routledge.

Hajdarpašić, Edin. (2019, 20 March). "How a Serbian war criminal became an icon of white nationalism,". Retrieved from The Washington Post website https://www. washingtonpost.com/outlook/2019/03/20/how-serbian-war-criminal-became-anicon-white-nationalism/. Accessed 19 September 2019.

Hobsbawm, Eric. (2012). Nations and Nationalism since 1780. Cambridge, Cambridge University Press.

Hodson, Garth Massey \& Sekulic, Dusko. (1993). "National Tolerance in the Former Yugoslavia." Global Forum Series Occasional Papers. Durham, N.C.: Center for International Studies, Duke University. December, no. 93-01.5.

Horsman, Reginald. (1986). Race and Manifest Destiny: Origins of American Racial Anglo-Saxonism. Cambridge: Harvard University Press.

Ignatiev, Noel. (1995). How the Irish Became White. New York: Routledge.

Japin, Arthur. (2002). The Two Hearts of Kwasi Boachi. New York: Vintage.

Karpat, Kemal H. (1982). "Millets and Nationality: The Roots of the Incongruity of Nation and State in the Post-Ottoman Era." In Benjamin Braude \& Bernard Lewis (Eds.), Christians and Jews in the Ottoman Empire: The Functioning of a Plural Society, Volume 1: The Central Lands (pp.141-169). NY: Holmes \& Meier Publishers.

Kasapović, Mirjana. 2001. Izbori, stranke i parlament 1990-2000. Zagreb: Fakultet Političkih Nauka.

Kaufmann. Chaim. (1996). "Possible and Impossible Solutions to Ethnic Civil Wars." International Security 20(4), 136-175.

Mann, Michael. (1999). "The Dark Side of Democracy: The Modern Tradition of Ethnic and Political Cleansing," New Left Review, no.235 (May-June), pp.18-45.

Marable, Manning. (1993). "Beyond racial identity politics: Towards a liberation theory for multicultural democracy." Race and Class 35(1), 113-130.

Maschino, Maurice T. (2002, juin). Etes-vous sûr d'être français. Le Monde Diplomatique, no.579.

McCarthy, Justin. (1995). Death and Exile: The Ethnic Cleansing of the Ottoman Muslims, 1821-1922. Princeton: Princeton University Press.

Oliveira-Roca, Maria. (1991). “Demografski profil hrvata, srba i jugoslovena u Hrvatskoj: Razlike u prostornom razmještaju i socio-demografskoj strukturi ekonomski aktivnih hrvata, srba i jugoslavena u Hrvatskoj u 1989.” In Bahtijarević and Lazić 1991.

Pupovac, Milorad. (1991). "Stavovi govornika hrvatskog ili srpskog prema jeziku i pismu.” In Bahtijarević and Lazić 1991. 
Roediger, David. (2005). Working Toward Whiteness: How America's Immigrants Became White. NY: Basic Books.

Sciolino, Elaine \& Cohen, Roger. (1995, November 23). In U.S. Eyes, 'Good' Muslims and 'Bad' Serbs Did a Switch. New York Times, pp.1, A10.

Sejdić and Finci v. Bosnia and Herzegovina. (2009). European Court of Human Rights. Online at https://hudoc.echr.coe.int/eng\#\{\%22itemid\%22:[\%22001-96491\%22]\}. Accessed 18 September 2018.

Stefanović, Djordje. (2005). "Seeing the Albanians through Serbian Eyes: The Inventors of the Tradition of Intolerance and Their Critics, 1804-1939." European History Quarterly 35(3), 465-492.

Todorova, Maria. (1997). Imagining the Balkans. NY: Oxford University Press.

West, Cornel. (1994). Race Matters. New York: Vintage Books.

Živanović, Maja (2019, March 19). "New Zealand Mosque Gunman 'Inspired by Balkan Nationalists'," Balkan Insight. Online at https://balkaninsight.com/2019/03/15/newzealand-mosque-gunman-inspired-by-balkan-nationalists/ (accessed 20 September 2019).

\section{ДЕЈТОН И ДЕСНИЧАРСКИ НАЦИОНАЛИЗАМ НА ЗАПАДУ}

Сажетак: Чланак се бави питањем зашто су западне силе које су тврдиле да су опредељене за мултикултурализам уобличиле постконфликтни споразум за Босну и Херцеговину, који је учврстио етнизацију територија, што је био циљ локалних етнонационалистичких елита. Конкретно, зашто су званичници из друштава у којима су крајње десне снаге, које се сматрају маргиналним, с идеолошким ставовима врло сличним националистичким снагама у Босни, прихватиле то гледиште као основу Дејтонског споразума? Рад одговара на ово питање разматрајући начин на који је изграђен политички простор у либералним демократијама Запада и начине на које већина у тим државама замишља тај политички простор. У раду се такође прави паралела између центристичких званичника који су одобравали Дејтонски споразум и успона десничарских нативистичких снага у њиховим друштвима.

Кључне речи: Босна и Херцеговина, Дејтонски споразум, етнички сукоб, ратови у Југославији, постконфликтни споразуми, мултикултурализам, национализам 